\title{
フリーピストンエンジンリニア発電システムにおける ばね特性を考慮した共振系出力分散制御の有効性と動作範囲の設定
}

\author{
Effectiveness and Setting Operation Range of Resonant Output Distribution Control \\ in Consideration of Spring Characteristics on a Free-Piston Engine Linear Generator System
}

佐藤 光秀 ${ }^{* 1,3}$ (学生員), 榆井 雅已 ${ }^{* 2}$ (正員), 山中 雄一朗 ${ }^{* 3}$, 村田 紘庸 ${ }^{* 3}$,

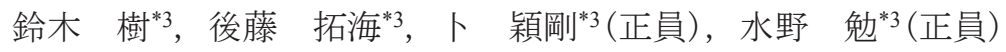

Mitsuhide SATO (Stu. Mem.), Masami NIREI (Mem.), Yuichiro YAMANAKA, Hironobu MURATA, Tatsuki SUZUKI, Takumi GOTO, Yinggang BU(Mem.), Tsutomu MIZUNO (Mem.)

\begin{abstract}
A free-piston engine linear generator system is expected for use as a high-efficiency generator engine. The cupper loss is decreased using resonant output distribution control which limits the maximum electric current and uses the mover inertia for power dispersion. But this causes iron loss and spring heat loss is larger due to stroke extension. Therefore, we confirmed that the total loss decrease by using its control in the theoreticaly calculation and simulation. Furthermore, the variable damper control is effective for decrease at generation time in using non-linear spring.
\end{abstract}

Keywords: linear generator, free-piston engine, resonant, generation control.

(2017 年 10 月 26 日受付, 2018 年 1 月 24 日再受付, 2018 年 2 月 1 日再々受付)

\section{1 緒言}

\section{1 背景}

近年，自動車の持続可能社会の構築に向けた移動体 用電動力応用システムの技術開発が進められており [1], 2016 年には発電して航続距離を延ばすシリーズハ イブリッド方式の自動車が市販を開始した。このシス テムは, エンジンを発電専用とし, 回転形発電機で電 力を取り出して走行する。回転形発電機では, 最適な 回転数や出力を保ちながら動作させることができるた め, 発電効率が高い[2]。一方で, 燃料から動力を取り 出す熱効率の観点では, 従来のガソリン車と同等の 39\%程度と試算され, システム全体としての効率向上 の弊害となっている。

そこで，シリーズハイブリッド方式と同様に発電エ ンジンを有するフリーピストンエンジン発電(以下, FPEG)システムが注目される[3-6]。本システムは一般 に, 往復運動式の内燃機関であるフリーピストンエン ジンとリニア発電機とばねにて構成され, クランク機

連絡先：佐藤 光秀, テ386-1211 長野県上田市下之郷813-8, 長野県工科短期大学校 電子技術科,

e-mail: mitsuhide@ele.pit-nagano.ac.jp

${ }^{* 1}$ 長野県工科短期大学校 ${ }^{*}$ 長野工業高等専門学校

*3 信州大学工学部

構を使用せずに動力を電力に直接変換できるため, 機
械損失の低減が期待される。また, 排気損失の低減に 伴う熱効率向上も期待される。一方, 発電時には, 可 動子を往復運動させながら, リニア発電機を用いて電 力を回収する。本システムは, 振動系特有の端部での 速度低下や, 燃焼に対応させるための大制動力が起因 して, 一方向のみに回転させながら適した状態で発電 を続けられる回転形発電機よりも, 単純には発電効率 が低下すると考えられる。一方, フリーピストンはク ランク機構のように動作範囲が束縛されないため, 発 電制動力の調整でピストン動作を制御可能である。つ まり, FPEG システムは, 効率を考慮したピストン動 作の制御が可能となれば, 自動車用発電エンジンの革 新的技術となりうるポテンシャルを秘めている。

\section{2 目的}

これまでに筆者らは, FPEG システムにおいて, 共 振系出力分散(Resonant Output Distribution)制御(以下 ROD 制御)を検討し, 銅損の削減に対寸る優位性を報 告した[7]。ROD 制御は, 機械共振を考慮して発電制 動力の設定を变え, ピストン慣性やばね反発力を利用 しながら, 膨張・圧縮の各行程間の出力均一化を図る ものと定義する。これにより,一定出力を保ちながら, 高効率な状態で発電を続ける回転形発電機の動作に近 づけることが可能となる。しかし, 発電制動力の設定 に伴うピストンストロークの違いがエネルギー変換効 
率に与える影響を考慮した理論は検討されていない。 また, ば㸚力の特性を考慮して動作範囲を設定する手 法を検討することで，さらなる出力増が期待される。 そこで，本報では，理論計算とシミュレーションによ り，以下の 2 点を明らかにすることを目的とした。

1）ばね損失を考慮した ROD 制御の有効性と有效範 囲の判断方法

2) ばね反発力の特性を考慮して出力向上を図るた めの ROD 制御の範囲設定方法

\section{2 システム構成とシミュレータ}

\section{1 物理モデル}

FPEG システムの物理モデルを図 1 に示した。燃焼 室ではエンジン燃焼力 $F_{\mathrm{c}}$ を作用させ，質量 $m$ のピス トンをばね反発室に向かって動作させる。ばね反発室 では，ばね反発力 $F_{\mathrm{g}}$ が燃燒力と反対方向に作用し，ピ ストンを燃焼室に押し戻す。この動作を繰り返すこと で往復運動させる。ピストンには永久磁石を取り付け, 周囲にコイルを配置して磁石可動形リニア発電機とし, ピストンの往復運動を利用して発電させ，発電制動力 $F_{1}$ を作用させる。運動方程式は式(1)である。

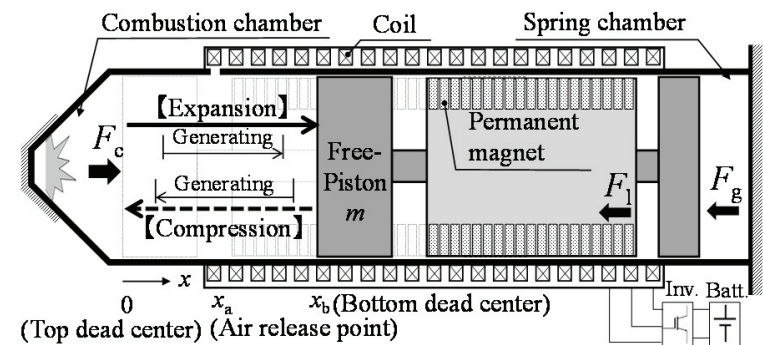

$$
m \frac{\mathrm{d}^{2} x}{\mathrm{~d} t^{2}}=F_{\mathrm{c}}-F_{\mathrm{g}}-F_{1} \quad(\mathrm{~N})
$$

ここに， $x$ :ピストン位置 $(\mathrm{m})$ である。

\section{2 効率シミュレータ}

MATLAB-Simulink にて, 運動方程式と回路方程式 を連成させた図 2 の効率シミュレータを製作した。

(1)作用力

燃焼力 $F_{\mathrm{c}}$ は, 時間変化する燃焼熱発生量を断熱変化 のモデルに考慮した式(2)で求める。ばね反発力 $F_{\mathrm{g}}$ は式 (3)の線形モデルと式(4)の非線形モデルを考慮する。

$$
\begin{aligned}
& F_{\mathrm{c}}(t)=A_{\mathrm{c}}\left\{p_{\mathrm{c}}(t-\Delta t) \times\left(\frac{V_{\mathrm{c}}(t-\Delta t)}{V_{\mathrm{c}}(t)}\right)^{\kappa}\right. \\
& \left.+\frac{\Delta \mathrm{Q}_{\mathrm{c}} \times\left(\Delta t / \Delta t_{\mathrm{Q}}\right) \times(\kappa-1)}{V_{\mathrm{c}}(t)}\right\}(\mathrm{N}) \\
& F_{\mathrm{g}(\text { linear })}(t)=K_{\mathrm{g}} x(t)+F_{\mathrm{a}}(\mathrm{N}) \\
& F_{\mathrm{g}(\text { non-linear) }}(t)=A_{\mathrm{g}} \times p_{\mathrm{g}}(t-\Delta t) \times\left(\frac{V_{\mathrm{g}}(t-\Delta t)}{V_{\mathrm{g}}(t)}\right)^{\kappa}(\mathrm{N})
\end{aligned}
$$

ここに， $A_{\mathrm{c}}$ :燃焼室断面積 $\left(\mathrm{m}^{2}\right), p_{\mathrm{c}}$ : 燃焼室圧力 $(\mathrm{Pa})$, $V_{\mathrm{c}}$ : 燃焼室体積 $\left(\mathrm{m}^{3}\right), \Delta \mathrm{Q}$. 熱発生量 $(\mathrm{J}), \kappa$ : 比熱比, $\Delta t$ : サンプル時間(s), $\Delta t_{\mathrm{O}}$ :熱発生量のサンプル時間 $(\mathrm{s})$, $K_{\mathrm{g}}$ :ばね反発定数 $(\mathrm{N} / \mathrm{m}), F_{\mathrm{a}}$ :ばね反発オフセット $(\mathrm{N})$, $A_{\mathrm{g}}$ : ばね反発室断面積 $\left(\mathrm{m}^{2}\right), p_{\mathrm{g}}$ : ばね反発室圧力 $(\mathrm{Pa})$, $V_{\mathrm{g}}:$ ばね反発室体積 $\left(\mathrm{m}^{3}\right)$ である。

\section{(2)発電制御}

発電制御では, ROD 制御で生成される電流指令に 基づき, 電流 PI 制御, ベクトル制御を用いて, イン バータに PWM 信号を入力し, 発電制動力 $F_{1}$ と発電出

Fig.1 Physical models of the FPEG system.

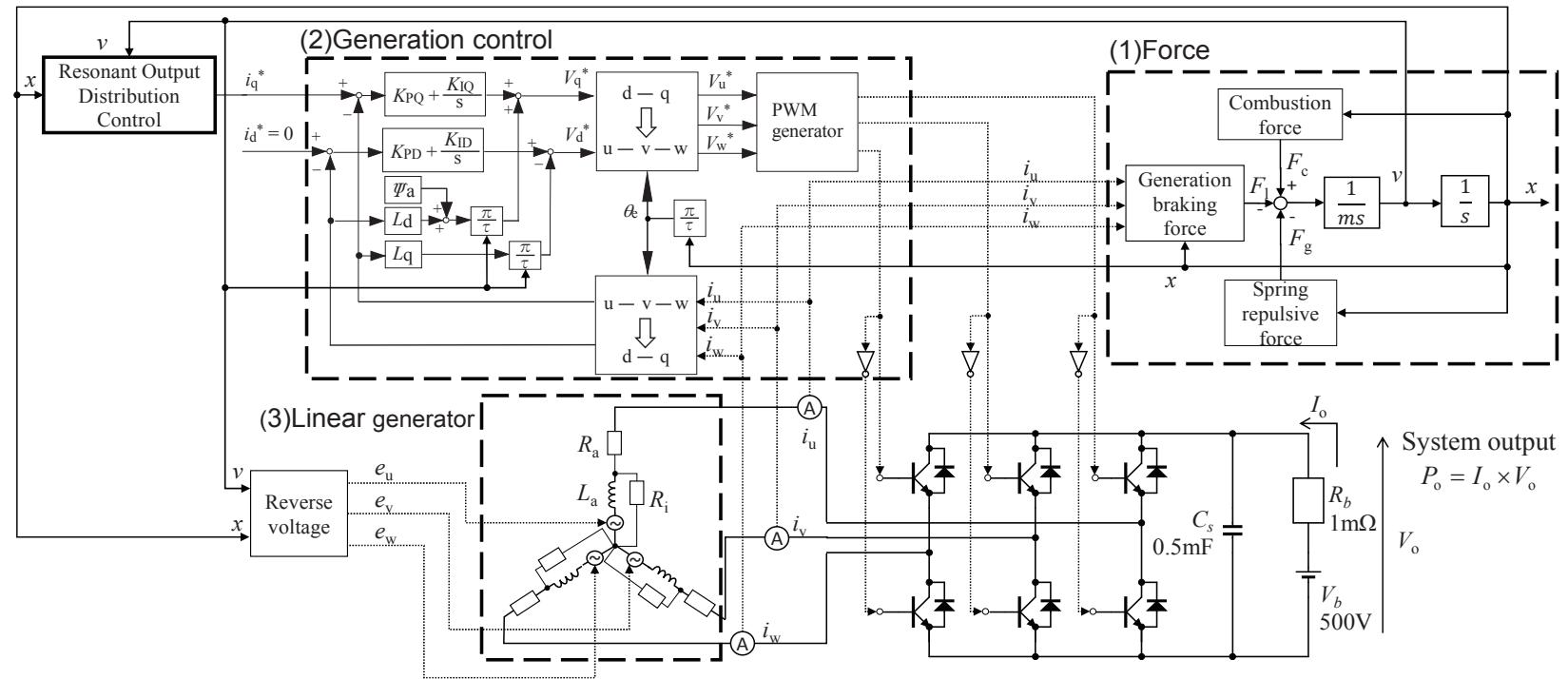

Fig.2 Block diagram of the FPEG simulator. 


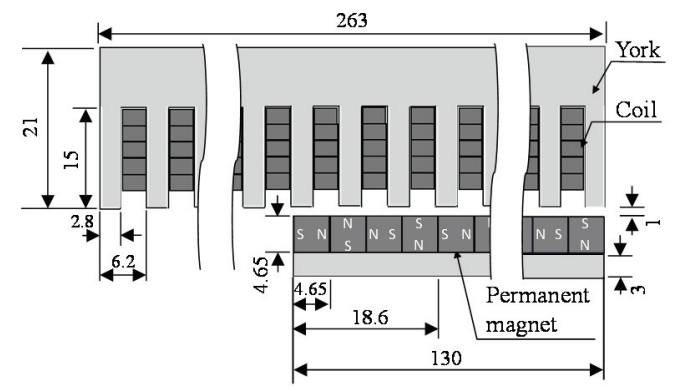

Fig.3 The FPEG structure (unit: $\mathrm{mm}$ ).

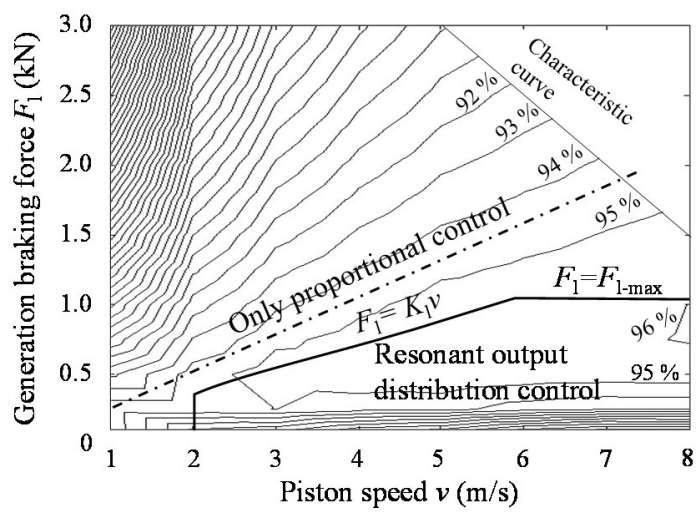

Fig.4 Efficiency map of the FPEG.

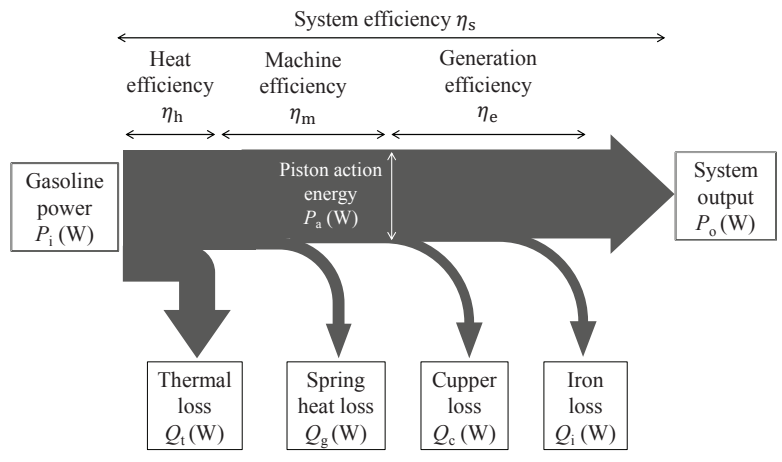

Fig.5 Energy flow of the FPEG system.

Table 1 The simulation conditions.

\begin{tabular}{l|l|l}
\hline Category & Item & Value \\
\hline \hline \multirow{5}{*}{ Generator } & External dimensions & $\varnothing 168 \times 263(\mathrm{~mm})$ \\
\cline { 2 - 3 } & Dimensions of mover & $\varnothing 128 \times 130(\mathrm{~mm})$ \\
\cline { 2 - 3 } & Mass of mover & $5.25(\mathrm{~kg})$ \\
\cline { 2 - 3 } & Number of coil turns & 5 \\
\cline { 2 - 3 } & Resistance of armature coil & $108(\mathrm{~m} \Omega /$ phase $)$ \\
\cline { 2 - 3 } & Inductance of armature coil & $1.8(\mathrm{mH} / \mathrm{phase})$ \\
\cline { 2 - 3 } & Thrust constant & $22(\mathrm{~N} / \mathrm{A})$ \\
\cline { 2 - 3 } & Number of pole pairs & 7 \\
\cline { 2 - 3 } & Flux linkage of coil & $0.065(\mathrm{~Wb})$ \\
\hline \multirow{5}{*}{ Engine } & Combustion scavenging position & $67(\mathrm{~mm})$ \\
\cline { 2 - 3 } & Boa diameter of combustion & $68(\mathrm{~mm})$ \\
\cline { 2 - 3 } & The volume of top dead center & $389,000\left(\mathrm{~mm}^{3}\right)$ \\
\hline
\end{tabular}

力 $P_{\mathrm{o}}$ を制御する[7]。 PWM 信号はキャリア周波数 $10 \mathrm{kHz}$ の三角波比較法で生成する。発電制動力は式 (5)で与える。ROD 制御の動作範囲設定のために, 速度に比例する発電制動係数 $K_{1}$ を定義する。

$$
F_{1}=K_{\mathrm{f}} i_{\mathrm{q}}=K_{\mathrm{l}} v
$$

ここに， $K_{\mathrm{f}}$ : 推力定数 $(\mathrm{N} / \mathrm{A}), i_{\mathrm{q}}: \mathrm{q}$ 軸電流 $(\mathrm{A}), v$ : ピ ストン速度 $(\mathrm{m} / \mathrm{s})$ である。

(3) リニア発電機

電磁界解析ソフトJMAG-Designer を用いて, 図 3 の表面磁石形リニア発電機を設計した[7]。困 4 はリ ニア発電機の銅損と鉄損を考慮した効率マップであ る。低推力領域で銅損の低減を達成し，ハルバッハ 配列とすることで推力特性を向上させた[8]。シミュ レーションで使用したパラメータを表 1 に示した。

(4)損失

シミュレータのエネルギーフローを眓 5 に示した。 ガソリンエネルギーを入力とし，バッテリーの電力を 出力とする。損失は, エンジンの熱損失 $Q_{\mathrm{t}}$, 空気ばね 損失 $Q_{\mathrm{g}}$ ，銅損 $Q_{\mathrm{c}}$ ，鉄損 $Q_{\mathrm{i}}$ を考慮する。

エンジンの熱損失は，上死点と掃気点 $x_{\mathrm{a}}$ に依存して 決まるため，本検討ではほぼ一定となる。空気ばねの 損失は，ピストンとシリンダの隙間から空気が流れ出 ることによる粘性損失と, 空気が圧縮されて温度上昇 することによる熱損失に起因する。粘性損失は，隙間 の大きさに依存するが，フリーピストンでは $0.01 \mathrm{~mm}$ と小さくすることができ, 空気の漏れはほぼないため, 熱損失のみを考慮する $[9]$ 。鉄損は等価鉄損抵抗 $R_{\mathrm{i}}$ を与 える。

\subsection{ROD 制御}

図 4 の実線は ROD 制御の動作範囲である。点線 で設定した比例制御の場合と比べて，銅損の削減が 可能となる $[7]$ 。本制御法の特徵は以下である。

1) 低速域では出力が低下し, 銅損の占める割合が大 きく，効率が下がるため，低速域では制動力を作用 させず，端部以外の中高速域で作用させる。

2) 損失の大きいエリアでの発電を抑制するために, 制 動力は $F_{1-\max }$ 以下として, 最大電流を設定する。また, 中速域では，共振系を実現し，発電制動力を速度に比 例させて与え，発電制動係数 $K_{1}$ を抑制する。

3) 2)に伴い共振点を考慮して，ばね反発係数を設定 し，ストロークを延長する。これにより，可動子慣 性と弾性エネルギーを利用して, 膨張行程で抑制し た発電量を圧縮行程へ分散させることができる。つ まり，最大出力は抑制され，銅損が改善される。 


\section{ROD 制御の有効性}

ストロークの延長により銅損は改善するが，鉄損や ばね損失に影響を与え, 出力やシステム効率が変動す る[5]。しかし，これまでにストローク延長や ROD 制 御の有効な範囲について損失を考慮して理論的に判断 した報告はない。ここでは，ストロークと損失につい ての理論的整理とシミュレーションを行う。

\section{1 減衰強制振動モデル}

ROD 制御の有効性の判断には, ストロークに依存す る平均速度を把握する必要がある。そこで, FPEGの 動作に類似した式(6)の減衰強制振動モデルで考える。 定常状態における一般解は式(7)で与えられ，その時の ストロークは式(8)となる。FPEG システムではピスト ンの往復動作に合わせて, 燃焼を開始させるため, 共 振点付近での動作となり, 角周波数は式(9)となる。よ って, 式(8)は式(10)に変形され, 燃燒力を一定と考え ると, ストロークは, 発電制動係数すなわち減衰係数 と, ばね定数に依存すると判断できる。また, FPEG システムのピストン動作に類似する正弦波を考えた場 合には, 平均速度は式(11)で与えられる。

$$
\begin{gathered}
m \ddot{x}+K_{1}{ }^{\prime} \dot{x}+K_{\mathrm{g}}{ }^{\prime} x=f(t)=F_{0} \sin \omega t \quad(\mathrm{~N}) \\
x=x_{\mathrm{b}} \sin (\omega t+\delta) \quad(\mathrm{m}) \\
x_{\mathrm{b}}=\frac{1}{\sqrt{\left(K_{\mathrm{g}}{ }^{\prime}-m \omega^{2}\right)^{2}+\left(K_{1}{ }^{\prime} \omega\right)^{2}}} F_{0} \quad(\mathrm{~m}) \\
\omega=\omega_{0}=\sqrt{\frac{K_{\mathrm{g}}{ }^{\prime}}{m}} \quad(\mathrm{rad} / \mathrm{s}) \\
x_{\mathrm{b}}=\frac{1}{K_{1}{ }^{\prime}} \sqrt{\frac{m}{K_{\mathrm{g}}{ }^{\prime}}} F_{0} \quad(\mathrm{~m}) \\
v_{\text {ave }}=4 f x_{\mathrm{b}}=\frac{2 F_{0}}{\pi K_{1}{ }^{\prime}} \quad(\mathrm{m} / \mathrm{s})
\end{gathered}
$$

ここに, $K_{1}$ :強制振動モデルの減衰係数 $(\mathrm{N} / \mathrm{m} / \mathrm{s})$,

$K_{\mathrm{g}}{ }^{\prime}$ :強制振動モデルのばね定数 $(\mathrm{N} / \mathrm{m}), F_{0}$ : 外力の 最大值 $(\mathrm{N}), x_{\mathrm{b}}$ : ストローク $(\mathrm{m}), \omega$ :外力の角周波数 $(\mathrm{rad} / \mathrm{s}), \delta$ :位相差 $(\mathrm{rad}), v_{\mathrm{ave}}$ :ピストン平均速度 $(\mathrm{m} / \mathrm{s})$, $f$ :運動周波数 $(\mathrm{Hz})$ である。

\section{2 損失の傾向}

\section{(1)鉄損}

鉄損を簡易的に求めるには, 式(12)のとおり, 渦電 流損失 $Q_{\mathrm{ie}}$ とヒステリシス損失 $Q_{\mathrm{ih}}$ を合計する。すなわ ち, ピストン速度 $v$ が早いほど鉄損は大きくなる。ROD 制御ではストローク量を伸ばすためには発電制動係数 を小さくする必要があり, 式(11)より, 平均速度は増
加し，鉄損が増大する傾向にある。各係数は JMAG-Designer を用いて試算した。

$$
Q_{\mathrm{i}}=Q_{\mathrm{ie}}+Q_{\mathrm{ih}}=1.94 \times v^{2}+6.45 \times v(\mathrm{~W})
$$

(2)ばね損失

空気ばね熱損失 $Q_{\mathrm{g}}$ は式(13)-式(15)の非燃焼時のピス トン熱損失モデルを用いて計算する[9]。熱伝達率 $\alpha$ と ばね反発室温度 $T_{\mathrm{g}}$ はストロークとピストンの平均速 度に依存するため，ストロークが伸びるほど，損失は 増大寸る傾向にある。

$$
\begin{gathered}
Q_{\mathrm{g}}=\alpha S_{\mathrm{g}}\left(T_{\mathrm{g}}-T_{\mathrm{s}}\right) \quad(\mathrm{W}) \\
\alpha=3.26 d_{\mathrm{c}}^{-0.2} p_{\mathrm{g}}^{0.8} T_{\mathrm{g}}^{-0.55}\left(2.88 v_{\text {ave }}\right)^{0.8}\left(\mathrm{~W} / \mathrm{m}^{2} \cdot \mathrm{K}\right) \\
T_{\mathrm{g}}=T_{\mathrm{g} 0}\left(\frac{V_{\mathrm{g} 0}}{V_{\mathrm{g}}}\right)^{\kappa-1} \quad(\mathrm{~K})
\end{gathered}
$$

ここに，S $S_{\mathrm{g}}$ ばね反発室表面積 $\left(\mathrm{m}^{2}\right), T_{\mathrm{s}}$ : 周囲温度 $(\mathrm{K})$, $d_{\mathrm{c}}$ :シリンダ径 $(\mathrm{m}), v_{\mathrm{ave}}$ :ピストン平均速度 $(\mathrm{m} / \mathrm{s}), T_{\mathrm{g} 0}$ :ば 被反発室初期温度 $(\mathrm{K}), V_{\mathrm{g} 0}$ : ばね反発室初期体積 $\left(\mathrm{m}^{3}\right)$ である。

(3)銅損

ROD 制御における銅損の低減効果について, 図 6 の銅損マップを用いて考える。図 6 の線 $\mathrm{b}$ は線 $\mathrm{a} よ り$ も発電制動係数 $K_{1}$ を低く設定し, 高速領域で最大制動 力を設定している。これにより, 式(10)からストロー

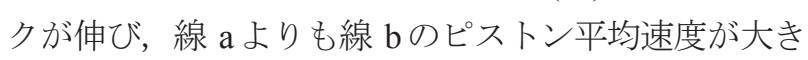
くなる。しかし，ピストンを往復動作させるには，式 (16)の作用仕事 $W_{1}$ が等しくなる必要があるため, ス卜 ロークの延長に伴い, 最大制動力が小さくなり, q 軸 電流が抑制される。銅損は $\mathrm{q}$ 軸電流の二乗に比例する ため, 本条件では, 最大制動力の二乗に比例し, ス卜 ロークの二乗に反比例して削減される。以上から, ス トロークの増加に伴い, 最大制動力が抑制され, 銅損 は削減される。

$$
W_{1}=\int F_{1} \mathrm{~d} x \quad(\mathrm{~J})
$$

\section{3 有効範囲の判断}

3.2 節の理論を用いると, ROD 制御では, 各損失が トレードオフの関係になると予想される。そこで, 減 衰強制振動モデルを用いて, 平均速度における損失を 理論的に求めた結果を図 7 に示した。合計損失 $Q_{\text {total }}$ はストロークに依存し, 最適值が存在する。すなわち, ROD 制御が有効となる範囲の存在が示唆される。また, 本制御においてストロークに大きく影響されるのは銅 損である。つまり，銅機械では銅損の割合が高まり， より明確な最適点が現れると見込まれる。 
ここで，実際にピストン動作を考慮するため図 2 の シミュレータを用いて損失を試算した。図 6 の線 a 線 b で動作させた場合の損失を表 2 に示した。ピスト ンの熱損失は, ばね反発室の圧力損失として考慮した。 ROD 制御を用いてストロークを増加させることで, 膨 張行程から圧縮行程に発電を分散し，銅損が抑制され た。一方で，鉄損と空気ば初熱損失は増加し，これは 理論計算の傾向と合致する。つまり, ストロークの最 適化によって合計損失の削減が達成可能であると判断 される。また，FPEG システムは減衰強制振動モデル で近似でき，簡易的に損失とストロークの傾向を見積 もることが可能である。実環境においても傾向は同様 になると見込まれるが，実機では 3 次元的に熱が拡散

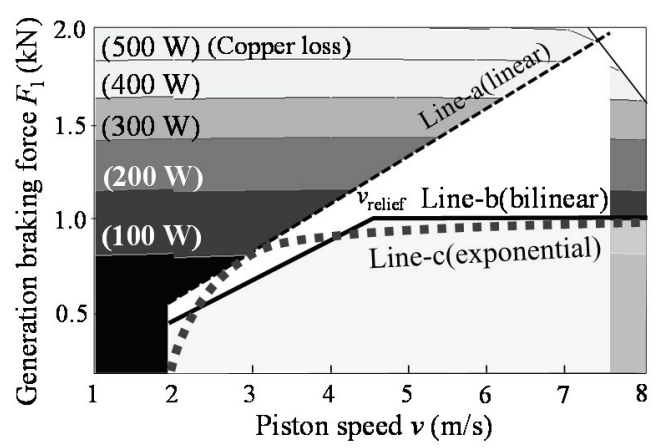

Fig.6 Effect of Copper loss reduction with mechanical resonant control.

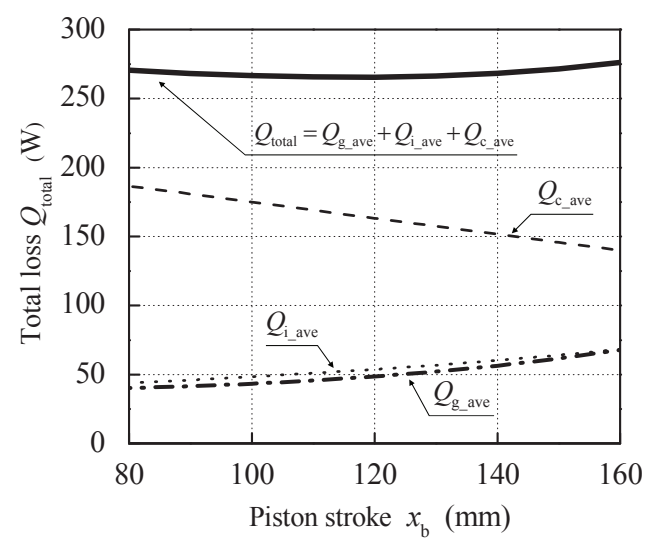

Fig.7 Relationship of the loss in a theoretical model.

Table 2 The comparison of the loss.

\begin{tabular}{l|c|c|c}
\hline \multicolumn{1}{c|}{ Item } & Symbol & $\begin{array}{c}\text { Line-a } \\
K_{\mathrm{l}}=201.3 \\
F_{\text {l-max }}=\text { non }\end{array}$ & $\begin{array}{c}\text { Line-b } \\
K_{\mathrm{l}}=194.7 \\
F_{\text {l-max }}=1287\end{array}$ \\
\hline \hline Stroke (mm) & $x_{\mathrm{b}}$ & 122.10 & 132.02 \\
\hline Cupper loss (W) & $Q_{\mathrm{c}}$ & 131.62 & 111.07 \\
\hline Iron loss (W) & $Q_{\mathrm{i}}$ & 69.35 & 74.28 \\
\hline Spring heat loss(W) & $Q_{\mathrm{s}}$ & 185.96 & 197.01 \\
\hline Total loss $(\mathrm{W})$ & $Q_{\text {total }}$ & 386.94 & 382.37 \\
\hline
\end{tabular}

し, 外部温度や壁面などの条件が異なるため, 機器の 特性による絶対值を考慮して, 最適值を判断する必要 がある。

\section{4 ばね特性を考慮した動作範囲の設定}

\section{1 ばねの特性}

一般的な線形ばねのばね反発力は式(2)の一次比例 で与えられる。空気ばねを用いて線形性を保つには, ピストンの振幅よりも空気室の断面積を非常に大きく することにより実現できるが[10], 自動車搭載を考慮 した場合には，寸法上の制約で難しい。そこで，式(4) の非線形ばねの特性について考える。

線形ばねと非線形ばねでは, 上死点付近の動作端部 において，ばね反発力の挙動が異なる。図 8 は線形ば ねと非線形ばねで動作させた場合のばね反発力の状態 である。非線形ばねでは，上死点近傍においてばね力 が $1 \mathrm{kN}$ 以下の低い状態で長く作用している。これによ り, 動作端部で低速で移動する時間が長く, ROD 制御 における発電抑制の時間が増え, 発電量が低下寸ると 推定される。具体的に発電抑制の時間を比較すると, 線形ばねは $2.6 \mathrm{~ms}$ ，非線形ばねは $3.9 \mathrm{~ms}$ であった。す なわち，非線形ばねでは，発電制動力の与え方を工夫 することが望ましい。

\section{2 発電抑制時間の短縮}

端部での発電抑制時間を短縮させる手法として，中 速時に発電制動力を増加させて素早く減衰させること を考える。そこで，減衰性が高く，広範囲のエネルギ 一吸収が可能な，可変ダンパーの考え方を取り入れた 発電制御を検討する。可変ダンパーは，折れ曲がり点 であるリリーフ速度 $v_{\text {relief }}$ を境界に減衰勾配が折れ曲が るバイリニア型と速度に指数乗で減衰力を与える指数 型があり，ほぼ等価であることが示されている[11]。

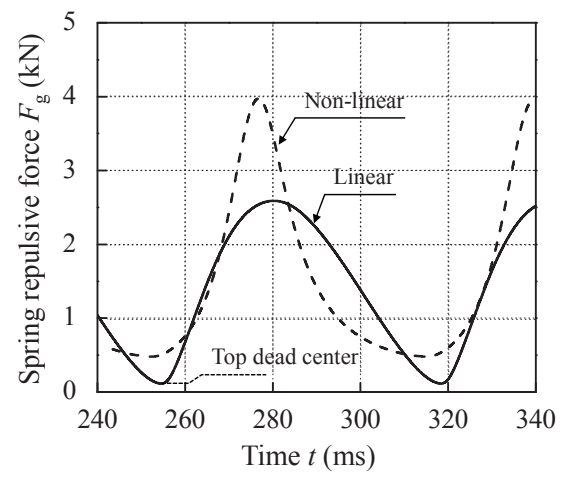

Fig.8 Differences of the spring repulsive force. 

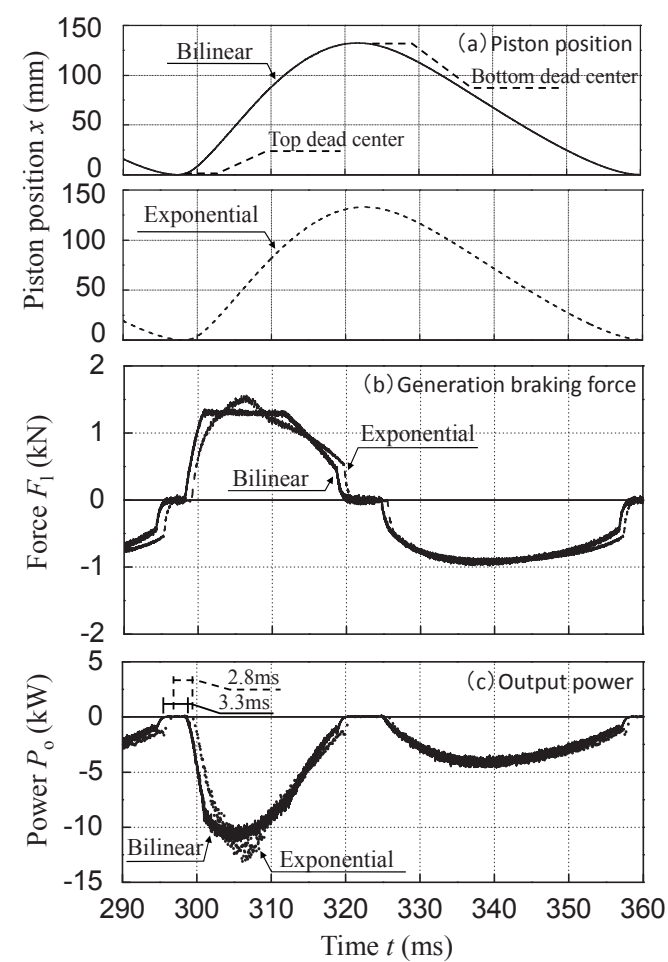

Fig.9 Simulation results of the control for high output.

本システムでの減衰勾配は発電制動係数と最大制 動力で定義され, 図 6 の線 $\mathrm{b}$ はバイリニア型と判断さ れる。そこで, 発電制動力の動作面積を等価とし, 最 大速度における制動力を近づけ, 図 6 の $\mathrm{c}$ 線を設定す る[11]。指数乗型を用いることで，ばね種類の変更時 でも端部での速度変化を大きく確保寸ることができる。 また，制動にかかる係数を細かく調整せずに，適切な

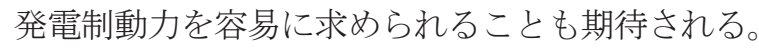

線 $\mathrm{c}$ の指数乗型におけるシミュレーション結果を図 9 に示した。(a)はピストン動作履歴である。指数乗型 の制動力を作用させてもピストンは往復動作できてい る。(b)は発電制動力の履歴である。バイリニア型と指 数乗型で発電制動力が異なる。高速域ではバイリニア 型が大きく, 中速域では指数乗型で大きく制動力が与 えられ，期待される制動力が作用している。(c) は出力 履歴である。動作端部での発電抑制時間が $0.5 \mathrm{~ms}$ 削減 され, 出力は約 $70 \mathrm{~W}$ 向上した。これは, 指数乗型を設 定したことで，中速域での制動力が大きく作用し，低 速移動時間が減り, 発電量が増加したことが大きく起 因している。ばね反発力の特性の違いを考慮し，可変 ダンパーと同様に制御することは，発電量の増大に有 効であると言える。また, バイリニアを等価換算した 指数乗型を利用することで，発電にかかる諸係数を細 かく設定せずとも，適切な状態を容易に求められた。

\section{5 結言}

FPEG システムにおける ROD制御の有効性を理論的 に確認した。シミュレーションでは, 発電制動力の動 作範囲を変えることで合計損失が約 $5 \mathrm{~W}$ 低減し，理論 計算と傾向が合致することを確認した。また，ばね反 発力の特性を考慮し, 適切な動作範囲を設定すること で出力向上に対する効果を確認した。

\section{謝辞}

本研究の一部は, (公財)TAKEUCHI 育英奨学会の研 究助成費にて実施した。ここに御礼申し上げる。

\section{参考文献}

[1] 移動体エネルギーストレージシステムの活用調查専門委 員会, 電気学会技術報告第 1380 号 移動体用エネルギー ストレージシステムとその応用, 電気学会, 2017.

[2] 水谷 良治, 立花 武, 森本 雅之, 赤津 観, 星 伸一, 自 動車の低燃費化に貢献する電動化技術, 電学論 D, Vol. 135, No. 9, pp. 884-891, 2015.

[3] 小坂 英雅, 秋田 智行, 守屋一成, 後藤 成晶, 堀田 義 博, 梅野 孝治, 中北 清己，フリーピストン発電システ ムの構築(第 1 報)ーシステムの基本動作検討一, 自動車 技術会論文集, Vol45, No.4, pp.683-689, 2014.

[4] 守屋 一成, 後藤 成晶, 小坂 英雅, 秋田 智行, 堀田 義 博, 梅野 孝治, 中北 清己, フリーピストン発電システ 厶の構築(第 2 報)一発電制御方法の検討一, 自動車技術 会論文集, Vol45, No.4, pp.691-697, 2014.

[5] 守屋 一成, 後藤 成晶, 小坂 英雅, 秋田 智行, 堀田 義 博, 中北 清己, フリーピストン発電システムの構築(第 3 報) 一ピストン運動の安定化と高効率化を実現する発電 制御方法一, 第 26 回内燃機関シンポジウム講演論文集, 40-20158053, 2015.

[6] C. Yuan, H. Feng, Y. He and J. Xu, Combustion characteristics analysis of a free-piston engine generator coupling with dynamics and scavenging, Energy, Vol. 102, pp. 637-649 2016.

[7] 佐藤 光秀, 榆井 雅巳, 山中雄一朗, 村田 紘庸, 卜 穎 剛, 水野勉, フリーピストンエンジンリニア発電システ ムの総合効率の最適化, 電気学会リニアドライブ研究会 資料, LD-17-034, 2017.

[8] 仲岩 浩一, 脇若 弘之, 田代 晋久, 小型円筒リニアモー 夕の推力と高調波歪みに関する研究と考察，日本 AEM 学会誌, Vol. 22, No. 2, pp.164-168, 2014.

[9] 高井 元弘, 非燃焼時のシリンダ内圧力を用いた TDC 位 置の正確な決定法について, 日本マリンエンジニアリン グ学会誌, Vol. 46, No. 3, pp.148-153, 2011.

[10] 日本機械学会, 振動のダンピング技術, 養賢堂, 1998.

[11] 渡邊 信也, 山崎 久雄, 高山 峯夫, 笠井 和彦, 免震層 の応答予測に用いる非線形粘性ダンパーのエネルギー評 価法 一 その 1 バイリニア粘性型と非線形粘性型の等 価則の確認一, 日本建築学会大会学術講演梗概集, pp.235-236, 2010. 